\title{
Zakat Institutions and Universities Strategic Partnership for Poverty Alleviation
}

\author{
Abu baker Ramadan Mohamed Hussain \\ Department of Finance and Economics \\ College of Business Administration, Taibah University
}

\begin{abstract}
Despite the global efforts to eradicate poverty around the world, avoid exists in the literature examining the role of an effective strategic partnership between universities and Zakat institutions as a core social protection provider in the Muslim world. This paper contributes to the literature in this area by assessing the prevailing patterns of collaboration between Zakat organizations and universities. The main objective is two folds; first, by appraising their potentialities, it establishes common interests that focus on shared goals and objectives; ethics and values; and networks and processes. The second is to propose strategic partnership framework. The proposed strategic partnership framework will increase penetration and outreach by bridging the knowledge gap, better targeted social protection components and improving communication and networks. The adoption of the framework will change how these institutions approach their goals and respond to community pressures providing variety of differentiated products and services to reduce poverty.
\end{abstract}

Keywords: Zakat, Strategic Partnership Framework, Poverty Alleviation, Zakat Institutions

\section{INTRODUCTION}

Poverty is a severe challenge to almost all countries. International organizations believe knowledge and knowledge sharing are core approach to alleviate poverty; they emphasize that partnerships are indispensable to achieving the common strategic goal (The World Bank, 2014; FAO, IFAD \& WFP, 2012). Partnering with the public to address societal needs are growing in number and importance and especially among organizations that think institutionally (Kanter, 2013). Recent trends on knowledge economy stresses on knowledge as enabler to eradicate poverty that shifted the global strategic goals and momentums from Millennium Development Goals (MDGs) towards Sustainable Development Goals (SDGs) promoting effective public, public- private and civil society partnerships, besides enhancing capacity building, data and monitoring, governance, finance and policy coherence (World Development Indicators 2016, and COMCEC, 2016).

To achieve SDGs goals, the declaration stresses on strengthening the means of implementation and revitalize the global partnership for sustainable development. This places Zakat institutions and universities strategic partnership as core social institutions to inspire sustainable development in the Organization of Islamic Countries (OICs).

Zakat is the third pillar of Islam, it means literally purification and growth (Gahf, 2010; IRIT, 2014). Legally, it means the transfer of ownership of specific wealth to specific individuals 
mentioned in the Holy Quran (Quran: 9:60). It implies that poor people have the right in the wealth of the rich (Hussain, 2015). Accordingly, Zakat institutions are legal entities designated to perform the religiously drawn objectives covering collection, distribution and management (Johari, 2014).

Global Poverty Map shows that 21 out of 48 Least Developed Countries are members of OICs, the organization shows 21 percent of the total population living under USD 1.90 (COMCEC, 2016). IRTI (2014) emphasized that multidimensional poverty measures within the OICs shows diverse records. However, challenges to achieving SDGs varied from political will, institutional capacity and lack of inclusive growth processes. Accordingly, metric statistics among OIC members entails the need for collaborative efforts to reduce poverty among organization's members (Ahmed, 2009; Abdebaki, 2016).

Many scholars underlined the unrealized role of Zakat institutions to effectively eradicate poverty (Hussain, 2015, IRTI, 2014). Others, including SESRIC (2015); Ahmed (2015); Ammani (2014); and Sarea (2012) questioned the international organizations criteria that linked poverty measurements to the rate of income, visualizing Zakat as an important "Socio-Financial Index" to reduce the gap between poor and rich within a country and between nations. In comparison between Zakat collection and distribution, Saad (2014) argues that there are several factors led to inefficiency in Zakat distribution including procedures and processes of Zakat funds distribution.

A partnership is collaborative relationships between two entities to work towards shared objectives $(\mathrm{CCF}$, 2010). A strategic partnership approach is considered by leading international organizations and developing countries as a means to eradicate poverty. It implies different meanings for universities across the globe (Banks, 2016). It varies from relationship for specific purpose, partnerships, and strategic partnerships that are resultsoriented, intensive, dynamic, long term, and ethically focused.

Universities are often not viewed by communities as valued partners in problem-solving (Sarena et al, 2003). In a similar vein, UNICEF (2009) asserts that universities have not yet reached their full potential of partnerships and collaborative relationships. It stresses the importance of strategic partnerships with civil society organizations, corporate sector and knowledge institutions. The Association of Business Schools (ABS) (2014) emphasized that universities have to include more explicit links between theory and practice giving more considerable attention to interdisciplinary programs. This requires strong local organizational partnerships to match market needs with local capabilities.

The existing literature asserts that more purposeful engagement is needed to assist the diffusion of knowledge. For instance, Porter (2007) emphasizes that the potentiality of the strategic approach between universities and community organizations can have a significant impact on regional economic revitalization without new funding. That the untapped capabilities of the universities envision sustained regional prosperity while contributing to the leadership and universities' long-term prospects. Likewise, Foster (2005) highlighted the need for collective attention to converting collected information into useful systematic intelligence indicators and to addressing local community problems. Broström, 
Anders, (2010) appraises collaborative R\&D with universities against their motive, desired social returns and subsidies. They concluded that, despite financial support by governments to boost R\&D collaboration, conceptualization of motives for and effects from such collaboration remains poor.

As developing countries move towards a knowledge economy, the link between local institutions (including Zakat) and universities is becoming the primary vehicle to achieve the nation's developmental goals. One of the stumbling blocks to integrating Zakat institutions and universities is to instil knowledge and R\&D mindsets into zakat organization's culture. This requires a shift from considering internal control compliance to a more sustainable permeates the entire organization.

By reviewing the relevant literature, this paper examines whether the rationale behind universities' engagement is driven by the same forces as Zakat institutions; or whether it represents a different type of engagement that need to be treated strategically different. Accordingly, the purpose of this paper is two folds: first, is to identify common interests that reflect the rationale behind the call for collaboration between Zakat institutions and universities. This lays the foundations for strategic partnership based on the unsatisfactory patterns of existing forms of collaboration and the potentialities of Zakat institutions and universities. The second aim is to recommend a framework for a strategic partnership between Zakat and universities as a tool to eradicate poverty.

\section{THE ESSENCE OF THE RATIONALE}

To establish a foundation for partnership, it is imperative to raise the forces inducing strategic partnerships' common interests. The rationale stems from three overarching sources namely: unsatisfactory existing patterns of collaboration; potentiality of Zakat institutions and universities:

\section{Unsatisfactory existing patterns of Zakat - universities partnerships}

Existing literature showed that universities - Zakat strategic partnership is yet to materialize and formalize to eradicate poverty. Zakat institutions in the Muslim countries differ in a way they collaborate and interact with universities. These differences resulted in varied social protection outcomes. Many scholars like Ahmed (2015); Dogarawa (2009), and IRTI (2014) identified two important deficiencies in Zakat practices and processes namely; inefficiency in Zakat distribution and entitlements procedures, while Zakatable funds (collection) that rely on wealth and financial assets are not strongly allocated against contemporary economic activities. The former attracted enormous attention among researchers highlighting the negligence of empowerment of the poor revealing that most poor people do not possess entrepreneurial and technical skills needed for wealth creation. However, the latter omits current economic activities and financial resources.

Similarly, in a search for excellence, universities tend to form shyaway direct collaboration with Zakat organization to tackle social protection activities and management (Clarke \& Feeny, 2007; Banks, 2016). Much research in this field has generated by faculty members on their interests, while 
others depend on government funding. As a result, weak resource management by the poor prevails together with fewer programs targeted vulnerable people, and most importantly how Zakat organizations increase their penetration and outreach (Sarea, 2012).

Typical conventional strategic directions for universities include; engaged research that aims to develop a high level of knowledge, skills and culture to serve local communities. Education is directed to improve students' employability and to leverage social responsibilities consolidating civic identity (Ausi 2013).

Perkmann (2013) suggests universities must improve their understanding of causal relationships between community engagement and research performance for identifying contemporary activities; and designing appropriate policy interventions that improve human capital and social safety net in dynamic nature of a knowledge economy.

Spatial experiences produced different methods of collaboration exacerbating poverty ratios. In Asia, SESRIC, (2015) and IRTI (2014) examined the interaction between universities and Zakat organizations in Indonesia, India and Pakistan. The results showed five different types of collaboration including student support, institutional (universities) support, infrastructure, events and dakwah activities. While in African countries such as Malawi, Uganda, Zambia and Mozambique, their current patterns of Zakat support to higher institutions focus on graduate student's support (Dahiru, 2016). That includes financial support (bursaries), accommodation and rental support and stationaries. Prioritizing these activities require a closer collaboration to identify students' entitlements, type of support, composition, duration and time.

Related activities by universities cover collaborative research, research chairs, training, consultancies, tailored courses and programs. Having the main objectives of these institutions to participate in community development, much of their objective to reap financial rewards showed insufficient formal engagement with Zakat institutions. Jacob et al. (2015) urged Higher Education Institutions (HEIs) to engage within their local community where they reside to have sustainable impact on society; likewise, communities must improve network with HEIs to maintain equal and positive partnership.

Mirroring recent practices of Zakat organizations, the state of knowledge remains relatively fragmented and tentative. For instance, Hussain (2015) highlighted the inadequateness of Zakat organizations' internal processes in using knowledge management approaches, especially for activities that support poor people asset management and the provision of local economic infrastructure. The literature suggests that some Zakat organizations across Muslim world, differ in absorbing knowledge produced by universities mainly in using information and knowledge that support certain sections of poor and vulnerable people (Saad, 2014).

\section{The potentiality of Zakat institutions}

Many scholars recognized the importance of reliable and dynamic local systems and institutions to achieve local economic development goals (Clarks, 2010; Bassi et al., 2014; Anand, 2011; World Bank, 2011). Zakat is the third pillar of Islam aims to bridge the gap between rich and poor (Quran, 9:60). Its institutions play a significant role in social protection and socioeconomic 
development (IDB, 2014; Hussain, 2014). Zakat acts as a core Islamic socioeconomic policy responsible for social protection and financial stability. As divine self-sustainable institutions, the prime functions of Zakat include collection, distribution and managing Zakat funds.

Recent global changes emphasized that Zakat institutions must reorganize themselves to cope better with contemporary challenges and pressures on poverty eradication and sustainable development. However, Zakat institutions encompass the following potentials:

First, Zakat organization characterized as a financially selfsustained organization (Saad, 2014). That Zakat collection contains all economic activities if Zakat conditions are met including enough Zakatable funs and the annuity of funds. Before disbursement, operational expenses and all necessary expenditure for collection, distribution and management will be covered. However, this involves research work and capacity building expenses to increase the efficiency and effectiveness of Zakat. This character assures the sustainability of the proposed partnership framework.

Second, global consensus to eradicate poverty led by the United Nation 'Sustainable Development Goals (SDGs) prompted developed and developing countries to accommodate these goals into their national strategies and policies. This implies the integration of all local organizations to focus on deeper, strong and effective strategic participation to strengthen and generate knowledge that can be absorbed and exploited by local communities. Their strategic focus concentrates on building and coordinating macro-level communities of practice to reduce poverty (Hussain, 2015). Research on social safety net acknowledges the potentiality of Zakat to deliver best results to combat poverty and increase social inclusion (Abdelbaki, 2016). As legal entities, Zakat institutions aim to strengthen social capital and blistering social assets; as they fully aware of social structures, that aids the design and implement more effective local development agendas.

Third, challenges of the knowledge economy pressurized local institutions to formulate effective partnerships to achieve their strategic goals within the national development framework. Among other advocates, the UN (2015) assumes effective partnerships enhance community involvement, institutional capacities, governance and strong accountability that help nations to accelerate the reduction of poverty. In this sense, Zakat institutions are core learning organizations that can create value for the poor and the needy if they exploit their knowledge to the benefit of their strategic objectives (Hussain, 2015). Zakat institutions are ethically trustworthy organization characterized by transparency, professional management and accountability to its stakeholders, (Abdelbaki, 2016).

Forth, modern knowledge economy and knowledge management overshadowed all voluntary, NGOs and community organizations' processes. Zakat economic activities and institutional governance entail the essence of knowledge economy components symbolizing religious commitments and socio-economic development objectives as strategic goals. The holy Quran specifies and priorities eight proceed to distribute Zakat funds that depend entirely on collection. The collected funds require comprehensive knowledge about existing economic activities, businesses, 
types of Zakatable funds, Zakat payees (individuals and organizations) procedures and operational processes. A typical Zakat institution governance and processes are summarized in the following figure.

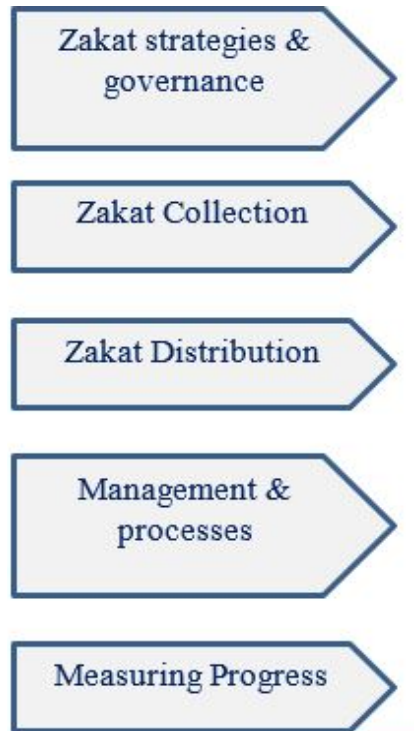

- Alienation of Zakat vision to national economic development strategies

- Communicate strategy with stakeholders.

- Identify Zakatable activities.

- Collection mechanism and measures.

- Classify Zakat funds.

- Define and redefine the eight categories identified in the holy Quran.

- Prioritize and quantify the distributed funds.

- Establish necessary policies, procedures and practices

- Promote communication with stakeholders.

- Develop outcome related measures.

- Assess programs and project.

Figure 1. Zakat Processes

Source: Prepared by Author.

Fifth, leading international organizations including the World Bank (2011), UNDP (2011), FAO, IFAD \& WFP (2012) stress on knowledge as the prime focus to eradicate poverty. Zakat institutions knowledge loop encompasses insight and foresight knowledge. These include data mining, information, systems, tools, technologies required for ongoing management and practices. The generated knowledge is, however, requires organizational alignment to national strategic approaches, changes in leadership and decision-making processes. By targeting the eight proceeds prescribed in the Holy Quran, (9:60), they have a critical inclusionary mechanism to reshape societal development goals.

\section{Potentialities of Universities}

Universities are an important source of knowledge creation and knowledge transfer (Yusuf, 2007; Clare, Chave, 2014). Their strategic directions denote how knowledge is exchanged to share and to promote exemplary practices and initiatives that have resulted from engaged research, education and services (Théron, 2014). In recent years, their role in enhancing economic growth and socio-economic development have mounted. Many scholars reveal that universities have given freedom to prioritize their own goals building effective engagement within the prevailing framework of shared value and organization's ethics (Banks, 2016; Broström, 2010, and Brennan, 2004). This new role assures the autonomy to create, disseminate and share knowledge to fulfil sustained development agenda.

However, they differ in how knowledge served societies to promote development and economic growth. Accordingly, diverse patterns of university-society interactions, commitment and motives have emerged to formalized different types of collaboration. Although, universities 
ability to create and share knowledge is the prime force for successful partnership by conducting relevant research activities covering preventive, remedial and development objectives. Other drives to address societal problems include:

a. New global trends encourage universities to materialize suitable culture to accommodate the needs of a knowledge economy by enhancing research, local networks, learning programs and objective-driven linkages. This necessitated universities to have a leading edge in research, technology and knowledge creation to effectively engage in realizing the global SDGs together with national, regional and local poverty reduction objectives.

b. The increased challenge to expand the university's academic engagement beyond the traditional objectives of teaching and learning and research. These include developing and delivering programs to stimulate the emerging local / community economic development activities while sustaining scientific research funds.

c. Recent recognition of the need for exploiting the capabilities of higher education institutions (universities) in strategic partnership plays a very significant role to achieve a community's development goals. In this sense, universities must reposition strategic partnership within their missions to achieve the desired goals. Such partnership should play a lead role in promoting socio-economic development that is necessary for the knowledge economy. d. In a similar vein, the demand for higher education continues to grow in developing world, particularly in Muslim countries. Universities' participation is still below expectations and remains significantly correlated with resource management, wealth creation and income distribution.

e. Rethinking the role of universities in growth and development necessitates the recognition of local and regional growth and community wellbeing; supporting socioeconomic mobility; Anticipation of future business needs and building talents and supports local organization's evidence-based policymaking.

These potentialities will offer insights into crucial Zakat institutions processes such as recognition of contemporary Zakatable financial resources and activities scrutinizing social protection priorities and approaches among others. Nevertheless, it gives and universities the necessary foundations for building solid societal strategic partnership.

\section{Common interests}

The successful strategic partnership relies on flexibility by both institutions to adapt their organizational goals and objectives, shared ethics and values with processes and networks. This is thought to create common strategic objectives and interests.

Zakat institutions are progressively adopting strategies to better access integrating sources of knowledge to identify Zakatable sources of funds and targeting specific section in the society known as Zakat proceeds. This builds a consensus to increase their interest to collaborate with universities. Similarly, a typical strategic mission of 
universities has moved beyond traditional teaching and research towards better-addressing community challenges and needs contributing directly to growth and development.

Accordingly, both institutions motivated by such common interests to improve societal socioeconomic developmental objectives. This will lead to building a useful foundation to propose strategic partnership framework. Figure (2) summarizes common grounds for a successful strategic partnership.

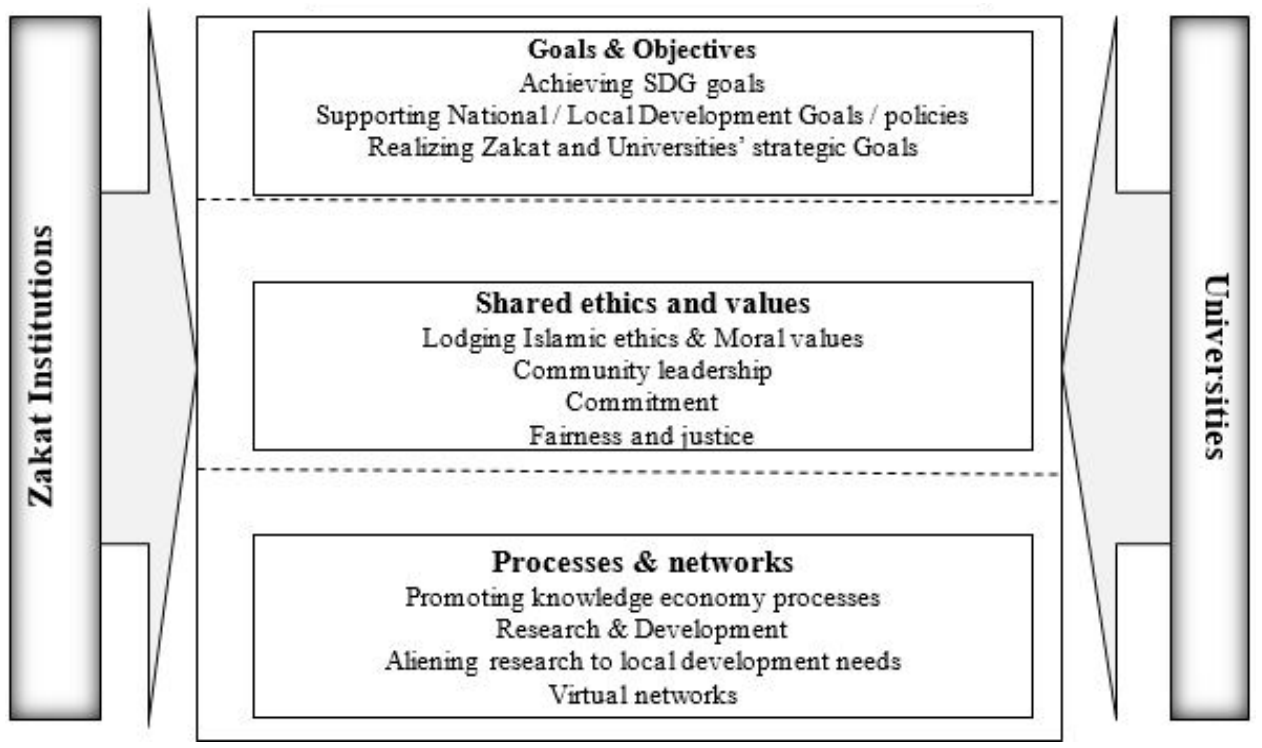

Figure 2. Common Interests

Source: Prepared by Author.

\section{a. Shared goals}

Local communities appreciate global SDGs goals announced by the UN, but they also treasure the relationship they have with their own local goals, including Zakat objectives. To complement these goals strong strategic partnership should take place to galvanize and formalize scattered and often isolated attempts. Both Zakat institutions and universities place themselves as anchor organizations at local level targeting sustainable development and knowledge transfer that well documented in their strategic goals and missions including supporting and achieving the nation's development goals while realizing their own strategic objectives.

\section{b. Ethics and values}

Zakat institutions and Universities are regularly exploring open and honest practices accompanied by ethics, values and transparency implanting the essences of fairness and justice. Their abilities to establish and promote core ethics and values in their operations and processes are based on their original terms of references. Universities are core sources of knowledge and technology while, Zakat institutions are religiousbased organizations seek to enforce Shariah guidelines lodging Islamic ethics and moral values and rules in financial transactions and financial management. The entrusted commitment implies them to become local leaders with 
the ability to perform their missions and plans across nations, regions and at local level.

c. Processes \& Networks

Development goals have changed across frontiers prompted Zakat institutions and universities to rethink their objectives, priorities and processes. Manyika, et al. (2013) indicated a shift in the demand for education, training and knowledge drives the customers (including poor people) to look for more services and innovative products (goods and services). In accordance, both institutions have to tie research to local development needs, utilizing knowledge economy processes to empowering poor and vulnerable people. However, building virtual networks and consolidating research objectives and processes become an important vehicle to achieve common goals.

\section{THE FRAMEWORK}

The success of an effective strategic partnership between Zakat institutions and universities inevitably rests on realizing the common goals. This involves formalizing strategic partnership; resolving challenges and acquiring certain competencies. It depends on mutual recognition of varied Zakat issues and process together with universities' community collaboration goals. To stay focus on crystalizing common interests and strategic goals; there is a need to accommodate partnership goals within their mission, developing necessary approaches to achieve them.

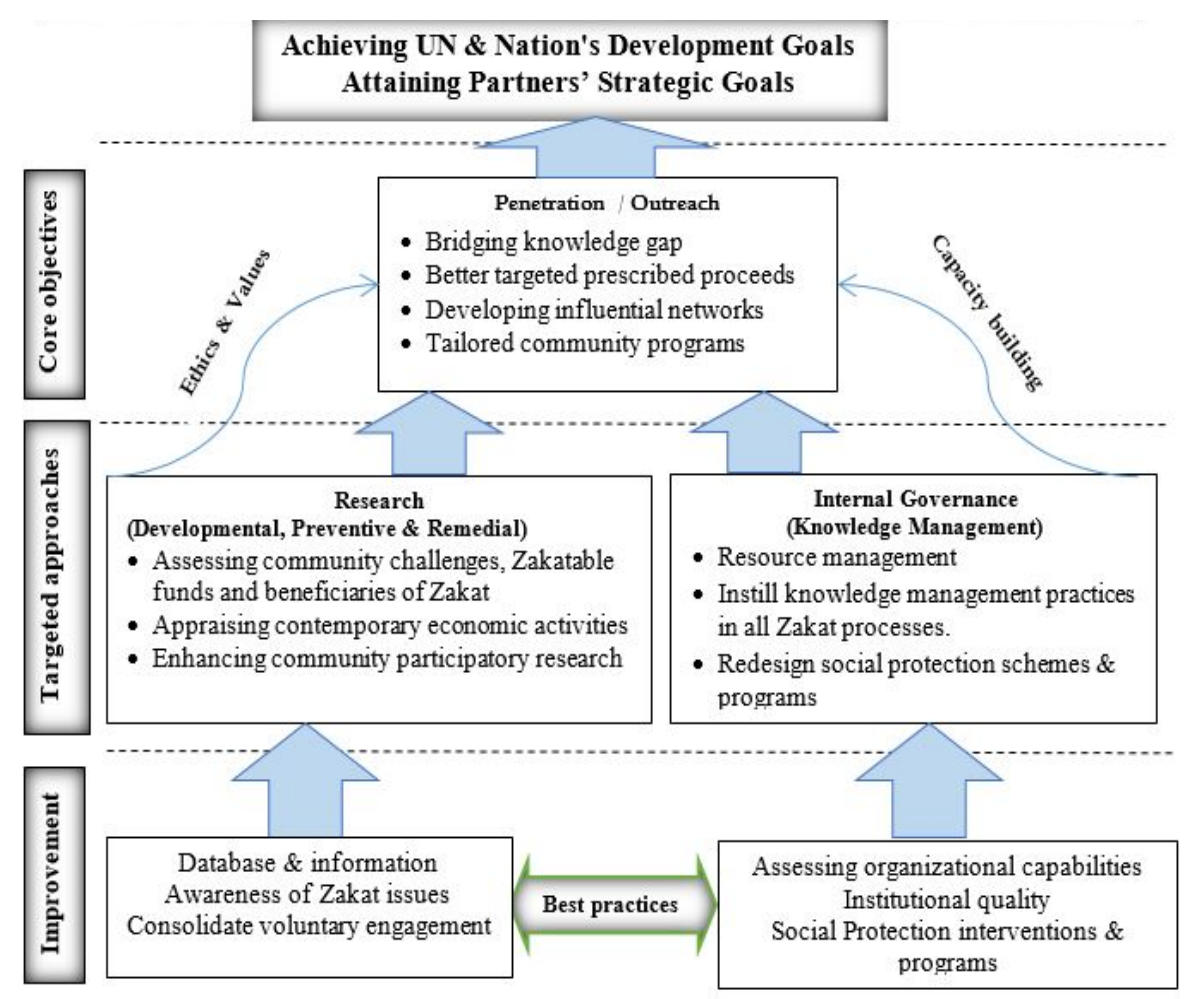

Figure 3. Zakat Institutions - Universities Strategic Partnership Framework

Source: Prepared by Author. 
Figure 3 summarizes Zakatuniversities strategic partnership. Based on the above rationale and common interests, it rests on two tiers to achieve its goals, the required improvements and targeted approaches. Improvement processes include strengthening database and information; raising the awareness of Zakat issues encompassing social protection and socioeconomic inclusion to enhance local development objectives.

Simultaneously, improvements entail internal organization and institutional quality to transform essential organizational capabilities. Progress on social protection schemes and program need to be carefully revised to accommodate the needed improvements.

Targeted approaches follow two different directions; first, the selected research domains develop appropriate gateways to assess community's challenges and emerging economic activities that Zakatable funds depend on, while redefining beneficiaries of Zakat (proceeds identified in the holy Quran). Since universities tend to develop high levels of knowledge and skills, research themes and processes will produce useful insights to understand community's social protection goals. In doing so the practices enrich not only community participatory research but also valid interpretation to their socioeconomics problems.

Second, approaching internal governance is the most crucial element in strategic partnership success. The framework will instil the essence of knowledge management in all Zakat processes (see figure 1). Most importantly, it develops result-based evaluation traditions forcing the processes of knowledge management governance. This implies redesigning social protection schemes and programs to integrate capabilities and incentives concurrently with the emerging changes in the labour market and community's goals and needs.

The proposed framework is thought to increase penetration and outreach, unlocking Zakat institutions and universities potentials leading to better resource management, and ways to improve societal wellbeing. Penetration, in this sense, will foster new community practices that facilitate cultural values to support knowledgebased growth and sustainable development.

It promotes capacity building that signifies ethics and values approaches; empowering local organizations, and community members' capabilities to tackle poverty and other societal problems. The framework supports knowledge exchange activities, including collaborative research, consultancy, training, risk analysis and resource management and procedures.

\section{WHAT STRATEGIC PARTNERSHIP FRAMEWORK CAN DO?}

Controlling the joint strategic actions enhances the shift towards a more strategic approach to realizing institutional objectives and a country's strategic development goals. It assumes to share risks and benefits in attaining social protection goals that promote inclusionary measures accompanying ethics and values and capacity building. In particular, penetration and outreach will enhance the following outcomes:

\section{Bridging knowledge gap}

The proposed framework will bridge the knowledge gap which is necessary for emerging activities and modern working lives. The process enriches community development programs, maintaining local accessibility and appropriate education to 
meeting labour market demand. Formal agreements with universities to cooperate for long term with Zakat organizations strengthening decision making processes and exchange more information and get more knowledge that improves outcomes, processes and fulfilling national and organization's objectives.

\section{Better targeted social protection components}

The strategic partnership will relentlessly advice on whether current Zakat funds can be better targeted "the eight proceed" to provide effective support and fair access and identifies Zakatable sources of funds in a sustainable manner that consolidating social capital and social assets.

\section{Improving communication \& Networks}

The proposed strategic partnership framework builds a robust continual database that improves the depth and relevance of decision making. Its networks frontiers including vertical and horizontal relationships deepen penetration and outreach stimulating robust and inclusive local economic development. This makes antipoverty policies more effective. The framework considers feedbacks from previous programs as a key ingredient in designing new programs.

\section{Tailored Community Programs}

Within the domain of Zakat institutions and universities, there are varying programs addressing different themes while targeting various sections in the society. The framework will strengthen existing programs while identifying new ones to tackle specific social problem and emerging challenges. This requires scrutinizing closely Zakat programs relying on the nature of its classified and identified activities and beneficiaries. As for universities, tailored programs focus on labour market needs and required knowledge and how to share its outcomes across society.

\section{CONCLUSION}

This study highlighted the importance of Zakat institutions as an Islamic organization to curtail poverty situations and to achieve social protection goals. It presents the role of Universities as a powerhouse that generates knowledge as enabler to attain sustainable development goals. The paper underlines three different forces that lay the foundation of strategic partnership between Zakat institutions and universities; including the unsatisfactory existing patterns of collaboration; the potentiality of Zakat institutions to reduce the gap between rich and the poor; and the aptitude of universities to strengthening the current knowledge reservoir to eradicate poverty.

It identifies common interests ranged from shared development goals; ethics and values; knowledge processes and networks. Accordingly, the paper proposes a strategic partnership framework that will reinforce penetration and outreach including; first: it formalizes strategic partnerships that institutionalize social problems within universities' development objectives. Such collaboration provides a better understanding of poverty and the poor while it generates a variety of differentiated products and services to reduce poverty.

Second, methodologically, it alters how institutions approach their societal goals and respond to community pressures fulfilling the shared socioeconomic values. That the dynamism of poverty requires a continuous search for assessment and appropriate means to address its components. Third, practical 
implications include; the provision of tailored programs focusing on vulnerable, poor people and certain societal segments. In this sense, the framework provides a broader and integrated practices to help Zakat institutions and universities to achieve their objectives more effectively and efficiently in releasing their social protection programs.

\section{REFERENCES}

Abdelbaki, H. H. (2016) The Impact of Zakat on Poverty and Income Inequality in Bahrain. Review of Integrative Business \& Economics Research; Vol. 2, No. 1, pp. 133 154.

Abreu, M, Grinevich, V., Hughes, A., Kitson, M., Ternouth, P. (2008) Universities, Business and Knowledge Exchange. The Council for Industry and Higher Education.

Ahmed, F. O., (2009) Zakat Funds and Wealth Creation. Review of Islamic Economics; 66(3), pp. 577 $-593$.

Ahmed, R., Othman, A. and Salleh, M. (2015) Assessing the Satisfaction level of Zakat Recipients Towards Zakat Management; Science Direct, Procedia-Economics and Finance $140-151$.

Ammani, S.; Abba, S. A.; Dandago, K. I. (2014) Zakat on employment income in Muslim majority states of Nigeria: Any cause of alarm; Procedia Economics and Finance.

Banks, C. (Ed), (2016) Global Perspectives on Strategic International Partnerships: A Guide to Building Sustainable Academic Linkages; Institute of International Education IIE.

Begin, B. et al (2006) Trends in poverty and welfare alleviation issues;
Nova Science, Publisher, Inc. New York.

Brennan, J., King, R., Lebeau, Y. (2004)

The Role of Universities in

Transformation of Societies: An International Research Project. Centre For Higher Education Research \& Information; ACU.

Broström, Anders, (2010) Firms' Rationales for Interaction with Research Universities and the Principles for Public Co-Funding. Journal of Technology Transfer. Available at SSRN: https://ssrn.com/abstract=1 640344

Clarke, M., Feeny, S. (Eds.) (2007) Education for the end of poverty implementing all the Millennium Development Goals; Nova Science, Publisher, Inc. New York.

Dahiru, M. A (2016) Glimpses from Zakat sector in sub - Saharan Africa; IIIBF\&IBF available at: http://www.iiibf.com/glimpsesfrom-zakat-sector-in-sub-saharanafrical

Dogarawa, A. B. (2009) Poverty Alleviation through Zakat and Wagf Institutions: A Case for the Muslim Ummah in Ghana. MPRA Paper, No. 23191.

EL Khuluqo, I. (2016) The Role of Zakat in National Economic Development; International Journal of Business Economics and Law; Vol. 9, No. 5, pp. 214 223.

Emmanuelle, F., M. Tomlinson, and R. Walker (2013) Poverty, Participation and Choice, Joseph Rowntree Foundation, Cambridge.

FAO, IFAD \& WFP. (2014) The State of Food Insecurity in the World 2014: Economic Growth is necessary but not sufficient to accelerate 
reduction of hunger and malnutrition. Rom: FAO.

Foster, A. (2005) Realizing the Potential: A review of the future role of further education colleges. DfES publications. Available at http://bit.ly/1vUPbSJ.

Gahf, M. (2010) Principles of "Figh" renewal and of "Ijtihad" in Zakat institutions and Islamic Banking; Israa, International Islamic Finance; Vol. 1 No. 1.

Hussain, A. (2015) Can Zakat Institutions Adopt Consumer Centric Knowledge Management Successfully? In Kaufmann "Handbook of Research on Managing and Influencing Consumer Behavior" IGI pp. 508 533.

IRTI and Thomson Reuter, (2014) Islamic Social Finance Report 2014. Thomson Reuter.

Islamic Development Bank (IDB), (2016) Key Development Indicators for the IDB Member Countries - statistical Yearbook. No. 36.

Jacob, W. J., Sutin, S. E., Weidman, J. C. and Yeager, J. L. (Eds.) (2015) Community Engagement in Higher Education: Policy Reforms and Practice. Sense Publisher.

Johari, F., Ab Aziz, M. R., Ibrahim, M. F., Ali, A. F. M., (2013) The Role of Islamic Social Welfare (Zakat) for the Economic Development of New Covert. Middle -East Journal of Scientific Research; Vol. 18, No. 3, pp. $330-339$

Johari, F., Ab Aziz, M. R., Ali, A. F. M., (2014) A Review on Literatures of Zakat Between 2003 - 2013; Liberary Philosophy and practice (e-journal). Paper 1175 http://digitalcommons.unl.edu/lip hilprac/1175
Kanter, R. M., (2013) How Great Companies Think differently; Harvard Business Review onPoint ISSN 1558-4879.

Lane, M., V. (2006) Trends in Poverty and Welfare Alleviation Issues; Nova Science Publisher, Inc. New York.

Perkmann, M., Tartari, V., Mckelvey, M., Autio, E., Sobrero, M. (2013) Academic engagement and commercialization: A review of the literature on university industry relations Research; Policy Vol. 42, pp. 423 - 442.

Porter, M. (2007) Colleges and Universities and Regional Economic Development: A Strategic Perspective; 2007 Forum for the Future of Higher Education. Cambridge.

Razak, M., Omar, Hashim, M., (2013) Overview of Zakat Collection in Malaysia: Regional Analysis. American Journal of Contemporary Research, Vol. 3 No. 8 pp. $140-148$.

Saad, R., Abdul Aziz, N. and Sawandi, N. (2014) Islamic accountability framework in the Zakat funds management; Elsevier Ltd, Procedia - Social and Behavioral Sciences 164, pp 508 - 515.

Said, J. et al (2012) Composite Performance Measurement for Zakat Organizations; British Journal of Economics, Finance and Management Sciences, Vol. 4 (1).

Sarea, A. (2012). Zakat as a Benchmark to Evaluate Economic Growth: An Alternative Approach; International Journal of Business and Social Science, Vol. 3 No 18 pp. $242-245$.

Shirazi, N. S., (2014) Integrating Zakat and Waqf into the Poverty Reduction: Strategy of the IDB 
Member Countries. Islamic Economic Studies; Vol. 22, No. 1, pp. $79-108$.

Standing Committee for Economic and Commercial Cooperation of the Organization of Islamic Cooperation (COMCEC), (2016) CCO Brief on Poverty Alleviation; COMCEC Coordination Office.

Standing Committee for Economic and Commercial Cooperation of the Organization of Islamic Cooperation (COMCEC), (2016) Report on the implementation of the OIC/COMCEC strategy; COMCEC Coordination Office, OIC/COMCEC/32-16/D (39).

Standing Committee for Economic and Commercial Cooperation of the Organization of Islamic Cooperation (COMCEC), 2016, COMCEC Poverty Outlook 2016: Human Development in OIC. COMCEC Coordination Office.

Standing Committee for Economic and Commercial Cooperation of the OIC the Statistical, Economic and Social Research and Training Centre for Islamic Countries (SESRIC), (2015) Measurement of Poverty in OIC member countries: Enhancing National Statistical Capacities; OIC.

The Islamic Research and Training Institute (IRTI), (2014) Islamic Social Finance Report - 2014; Thomson Reuters.

Théron, I. B., Anderson, K. (Eds.), (2014) Knowledge in Action: University-Community

Engagement in Australia; Cambridge Scholars Publishing.

Thorpe, R. and Rawlinson (2014) The Role of UK Business Schools in Driving Innovation and Growth in the Domestic Economy, The Association of Business Schools (ABS).
UNDP (2011) Beyond Transition: Towards Inclusive Societies, Regional Human Development Report, UNDP.

United Nations Children's Fund (2009) UNICEF strategic framework for partnerships and collaborative relationships, UNICEF E/ICEF/2009/10.

Universities UK (UUK), (2015) The Funding Environment for Universities 2015: The Economic Role of UK universities. available at: www.universitiesuk.ac.uk

World Bank (2014) Knowledge in Development Note: Measuring Global Poverty. Washington, DC: The World Bank.

World Bank, (2012) World Development Report 2013: Jobs, Washington, DC.

World Bank. (2011) The State of World Bank Knowledge: Knowledge for development. Washington, DC: The World Bank.

World Development Indicators (2016) Featuring the Sustainable Development Goals, World Bank Group, Washington, DC.

Yusuf, S. Nabeshima, K. (Eds) (2007) How Universities Promote Economic Development; The World Bank, Washington DC.
Abu baker Ramadan Mohamed
Hussain,
Associate Professor, Taibah University, arhussain@taibahu.edu.sa, amirahram@gmail.com 